\title{
The Moderating Effect of Role Stressor on the Influence of Evolutionary Process Change Factors on Internal Customer Satisfaction in Telecommunication in Jordan
}

\author{
Sattam Jumah Al-Sardia ${ }^{1}$ \& Hartini Ahmad ${ }^{1}$ \\ ${ }^{1}$ Othman Yeop Abdullah (Oya) Graduate School of Business, University Utara Malaysia, Malaysia \\ Correspondence: Sattam Jumah Al-Sardia, Othman Yeop Abdullah (Oya) Graduate School of Business, \\ University Utara Malaysia, Malaysia. E-mail: sattam_007@yahoo.com
}

Received: November 6, 2013

Accepted: November 27, 2013 Online Published: January 26, 2014

doi:10.5539/ass.v10n4p114

URL: http://dx.doi.org/10.5539/ass.v10n4p114

\begin{abstract}
This study investigates the moderating effect of role stressor on the influence of leadership change, behavioral change, structural change, technological change and cultural change on internal customer satisfaction. As a result, a cross-sectional study design with a quantitative study approach was conducted, and data was generated through self-administered procedure from 354 respondents from three telecommunication companies in Jordan. A 3-step hierarchical regression analysis technique was used to analysis the data. The study found overall support for the moderating effect of role conflict and role ambiguity on the relationship between structural change, technological change and cultural change on internal customer satisfaction while on the contrary, role conflict failed to moderate the relationship between leadership change, behavioural change and cultural change on the internal customer satisfaction, and role ambiguity also failed to moderate the relationship between leadership change, behavioural change, structural change and technological change on the internal customer satisfaction. The study concludes that role conflict and role ambiguity may only play significant role on the influence of structural change, technological change and cultural change on internal customer satisfaction. The study contributes to the body of knowledge by providing additional insight on the role of role stressor in particular role conflict and role ambiguity in managing EPC in the telecommunication industry. The study also highlights some of its limitations and makes suggestions for future study in this domain.
\end{abstract}

Keywords: telecommunication, leadership change, behavioral change, structural, role stressor change, internal customer satisfaction

\section{Introduction}

The term Evolutionary Process Change can be explained as "the vast collection of philosophies, concepts, methods and tools, which are now being used throughout the world to manage quality", but at its core it's a management approach in a long-term to be successful through customer satisfaction (Filippini, 1997; Michalsk-Cwiek, 2009). Such approaches are useful when the terms "quality" is briefly understood by the managers (Ramasamy, 2005).

EPC is a management technique that today has become a tool of the first choice in many businesses' strategies most especially EPC philosophy which emphasizes the management of quality in all aspects and phases of a business that meets customer's expectations. Now, in an attempt to facilitate organization with higher quality levels, many of the organizations are utilizing self-assessment tools, to evaluate and gauge their present status on TQM and to strategies and plan decision for future operational excellences (Azhashemi \& Ho, 1999; Zink \& Schmidt, 1998; Arumugam, Chang, Ooi, \& Teh, 2009). In the recent times, it has become very clear that ICS is very important in the overall total quality management of a company. Therefore, it is important to investigate those key factors that are likely to influence the organizations' internal customers' satisfaction for an effective organizational total quality management.

Furthermore, an attempt by Fecikova (2004) to investigate the relationship between Evolutionary Process Change (EPC) factors and internal customers failed to produce a clear result as the study was argued to be too broad in nature. The evolutionary process change (EPC) which focuses on the "process approach in implementing incremental change can be instructive in building internal customer satisfaction culture. Besides, 
subsequent attempts by other studies such as Parasuraman, Zeithaml and Berryet (1988); Zeithaml, Berry and Parasuraman, (1996); Fisk, Brown and Bitner, (1993); Nicholls, Gilbert and Roslow, (1998); Taylor and Baker, (1994) only focus on external customer satisfaction as opposed to internal customer satisfaction. This suggests that additional variable is required to adequately explain the link between EPC factors and internal customer's satisfaction, and one such variable is role stressor which has been identified to impact on the internal customer satisfaction. Although, the study by Babin and Boles (1996) argued that role stressor should be considered as independent variables while a similar study by LeRouge, Nelson and Blanton (2006) believed that role stressor should be regarded as a mediating variable, however, role stressor can be best considered as a moderator in such that it would interact with the independent variables to predict the dependent variable. Quite unfortunately, study examining role stressor as a moderator seems to be lacking. In this study, role stressor is perceived to play a significant role in the relationship between EPC factors (leadership change, behavioral change, structural change, technological change and cultural change) and internal customer satisfaction. That is, it is assumed that role stressor would significantly strengthen the relationship between EPC factors and internal customer satisfaction. Therefore, this study investigates the moderating effect of role stressor on the influence of EPC factors on the internal customer's satisfaction.

\section{Literature Review}

\subsection{Leadership Change}

There is no doubt that the concept of leadership has gained a lot of considerable attention from authors in the domain of leadership (Ali, Sidow, \& Guleid, 2013; Attafar, Sadidi, Attafar, \& Shahin, 2013; Ganz, 2010; Hall \& Tolbert, 1977). Not only that, but also the concept has cut across almost every aspect of human endeavors including the organizations. One major aspect of leadership that is of major concerned for this study is the leadership change. Based on previous study by Rowold and Schlotz (2009), Howell and Merenda (1999) noted that leadership style greatly influence the performance of an organization which is determines by customers satisfaction and commitment. A similar study by Elenkov (2002) on Russian managers draw a conclusion that on a relationship between leadership behaviors, organizational performance and customer satisfaction. Felfe and Heinitz (2010) observed that customer usually shows more commitment and loyalty to an organization that the leadership is seen to be effective and productive. This loyalty and commitment is generated out of the service satisfaction and employee interaction enjoy by the customers which is being created by the management.

Change Leadership is championing the achievement of intended, real change that meets the enduring vision of an organization. It involves collaboratively developing and implementing ideas to achieve positive change from anywhere in the organization (Wagner et al., 2010). The change leader learns from other leaders and elders, models the vision, and encourages members of the public service to commit to and champion the vision (Karlsson, Parker, Hjerpe, \& Linnér, 2011). The change leader inspires others into new ways of thinking and doing business. The Criteria for Performance Excellence are built upon a set of core values and concepts (Roberto, Levesque, \& Team, 2012). These values and concepts are the foundation for integrating key business requirements within a results-orientated framework.

These values and concepts are embedded behaviors found in high-performing companies. In which one of these core values and concepts is leadership. A company's senior leaders need to set directions and create a customer focus, clear and visible values, and high expectations (Yang, 2011). The values, directions, and expectations should balance the needs of all stakeholders. The leaders need to ensure the creation of strategies, systems, and methods for achieving excellence, stimulating innovation and building knowledge and capabilities. The strategies and values should help guide all activities and decisions of the company (Appelbaum et al., 2011). Senior leaders should inspire and motivate the entire workforce and encourage involvement, development and learning, innovation and creativity by all employees. Through their ethical behavior and personal roles in planning, communications, coaching, developing future leaders, review of the company's performance, and employee recognition, senior leaders serve as role models, reinforcing values and expectations and building leadership and initiative throughout the company.

\subsection{Behavioral Change}

The organization is a workplace with many different elements and factors interplaying together to form a single entity. Griffin and Moorhead (2011) suggested that behavior in an organization can be viewed from three dimensions; the individual behavior that made up the organization, the individual behavior in the organization (the group) and the corporate organization behavior. This was also argued by Luthans and Avolio (2009) that organization behavior deals with the understanding, exploration and improvement of attitudes and behaviors of individuals and groups in the workplace. This concept was further studied in Fisher and to (2012) that individual 
and group behaviors have a great influence on organizational behavior.

When individual behavior is improved then there shall be a positive influence on organizational behavior, this was suggested by Kish-Gephart, Harrison and Treviño (2010) on their study on good and bad decision making and its effect in an organization. They argued that decision making attitude and behavior of individuals enhance the effectiveness and performance of the organization. Hence, motivation is perceived as a key factor in improvement of individual behavior within an organization to enhance effectiveness and performance. Argote and Miron-Spektor (2011) suggested that a well-motivated employee tends to be creative and having the right orientation towards customer relation. This was argued by Luo, Wieseke and Homburg (2012) that when employee is well motivated, it leads to employee satisfaction which generates customer satisfaction because a well-motivated employee tends to please the customer at all cost. This was also reported by Grandey, Goldberg and Pugh (2011) that a well-motivated employee tends to delivery sense of high quality performance in the organization; which explains the linkage between individual behaviors in an organization to customer satisfaction.

When a group is well motivated, it defined the effort they put into accomplishing a task and how long it shall take. This also shows the relation between motivation and satisfaction; a well-motivated individual shall have a strong effect on the organization (Lian, Ferris, \& Brown, 2012). The more satisfied an individual at the organization; the more motivated they shall do their job well which shall be seen in the management and treatment of their customer (Grandey, Goldberg, \& Pugh, 2011).

Griffin and Moorhead (2011) argument suggests that a motivated employee behavior enhances good customer behavior in term of satisfaction. Such behavior as organizational citizenship behavior (as used by Bienstock, DeMoranville, \& Smith, 2003), prosaically service behavior (Bettencourt \& Brown, 1997) customer orientation (Bettencourt \& Brown, 2003) and service orientation (Lytle \& Hom and Mokwa, 1998) have all been related to influence customer satisfaction and services. When customers perceived that employees are well motivated in their organization, it tends to make such customers committed to their respective relationship with the organization. This commitment tends to make the customer to develop positive behavior and attitude to the organization which makes them feeling welcoming and satisfaction due to the organization behavior (Adler \& Gundersen, 2008).

\subsection{Structural Change}

Organization can be structured in many different ways, depending on vision, objectives and future expansion. Andersen (2004) argued that organization strategy formulation leads to organization structure. The structure of an organization will determine the modes in which it operates and performs. Jacobides (2007) concluded that organizational structure allows the expressed allocation of responsibilities for different functions and processes to different entities such as the branch, department, workgroup and individual. This argument by Andersen (2004) and Jacobides (2007) were further studied by Zheng, Yang and McLean (2010) and they suggested that organization structure depends on the organization'sobjectives and strategy. Aghion, Bloom and Van Reenen (2013) described the two types of organization structures; centralized and decentralized structures. They reported that centralized organizational structures rely on one individual to make decisions and provide direction for the organization. Small businesses often use this structure since the owner is responsible for the company's business operations. Decentralized organizational structures often have several individuals responsible for making business decisions and running the business. Decentralized organizations rely on a team environment at different levels in the business. Individuals at each level in the business may have some autonomy to make business decisions. In the same scenario Garvin (1998) studied the three approaches to organization processes as work processes, behavioral processes and change processes. Hallerbach, Bauer and Reichert (2010) argued that these approaches defined the nature and methodology of how organization effectiveness and efficiency might be achieved. Whereas the role plays by customers cannot be reduced, thus, organizations are in essence, moving away from product or brand-centered marketing towards a customer-centered approach. Organizations are realizing that customers have different economic value to both organization structure and strategy implemented and are subsequently adapting their customer offerings and communications strategy accordingly.

\subsection{Technological Change}

Technological change is one major aspect of technology concept. Although, initial works on technology have centered on equipment (Clark \& Staunton, 1989). This is more reason why most definitions on technological change are often towards on equipment and production methods. For instance, Krell (2000) described technological change to mean automation and other capital-intensive production equipment that can be used in place of human methods. They acknowledged the importance of technological change in changing human lives 
across the globe. For example, they noted that technological change has assisted human beings and organizations to communicate effectively. Now, humans can effectively communicate directly with their work. As new technology is being deploys to enhance general business improvement, Meuter, Ostrom, Roundtree and Bitner (2000) suggested that self-service technologies are one of the major strategies to ensure customer satisfaction. The use of self-service technologies as an interpersonal communication strategy to expand customer's touch-points, the characteristic of an effective customer service process and system in experiencing significant changes (Boyer, Hallowell, \& Roth, 2002). This was justified by Anton and Phelps (2002) research on the usage of technology in business; it was found that the use of telephone and online communication for business related purposes had increased by $45 \%$. This movement away from eye contact method to technological mediated method implies improvement to the growth of the business (Ray, Muhanna, \& Barney, 2005). That is why the usage of technology is gaining customers service operations and business are easily transacted using electronic mail, instant massage, telephone and fax which most customers found very easier to use (Burke, 2002). More importantly, researchers have being studying the effect and impact of technology on business growth (Shankar, Rangaswamy, \& Smith, 2003). Many factors like attitude, behave, truth, continuous-usage, loyalty, satisfaction and others are being research to determines the impact of technology on business (e.g., Degeratu, Rangaswamy, \& Wu, 2000; Lynch \& Ariely, 2000; Shankar, Rangaswamy, \& Pusateri, 2001). However, collectively these works had suggested that technology change enhance customers' satisfaction unless the technology is easy and afford to be use by the customer.

\subsection{Cultural Change}

A number of researchers have shown that an organization's culture has a close link to its effectiveness (Goetsch \& Davis, 2010). Denison, Haaland, and Goelzer (2004) found that culture contributes to the success of an organization; this can be seen in how loyal and satisfied the customers are to the organization. Organizational culture is reflected in the way people perform tasks, set objectives, and administer the necessary resources to achieve objectives which have been discovered to have a direct linkage to the success of the company (Clark, 2006). It also affects the way individuals make decisions, feel, and act in response to the opportunities and threats affecting the organization; these actions and inactions form an impression on customers' mind. Adkins and Caldwell (2004) found that customer satisfaction was positively associated with the degree to which organization fit into both the overall culture and subculture in which they worked. A perceived mismatch of the organization's culture and what customer felt the culture should be is related to a number of negative consequences including dissatisfaction, deflection customers, and company perform. Also Burman and Evans (2008) argue that it is leadership that affects culture rather than management, and describe the difference. When one wants to change an aspect of the culture of an organization one has to keep in consideration that this is a long term project. Corporate culture is something that is very hard to change and employees need time to get used to the new way of organizing. For companies with a very strong and specific culture it will be even harder to change. This argument was also supported by Ogbonna and Harris (2000) when studying organization leadership, culture and performance that organizational culture can mediate the relationship between human resource practices and customer satisfaction, supporting a social context model (Ferris et al., 1998) for predicting customer satisfaction.

\subsection{Internal Customer Satisfaction}

Internal customer satisfaction is an off shot of the general term customer satisfaction which is as a result of a cognitive and affective evaluation, where some comparison standard is compared to the actual perceived performance (Oliver, 2010). It is described as the satisfaction derived by the internal customers within the organization (Earl, 2004).

Within the research domain, researchers have identified quite a number of tools essential for measuring internal customer satisfaction (Credit Research Foundation, 1999). Most of these tools are: the use of surveys, the focus groups formation, and one-on-one meetings schedule between managers in the respective departments and internal customers on a regular basis (Credit Research Foundation, 1999). The choice of any of these tools depends on the advantage and disadvantage they offer. However, it has been noted that among all other internal customer satisfaction tools, the use of internal customer survey seems to be more important, less demanding and more comprehensive in achieving internal customer satisfaction most especially when it is a priority for internal customer service to not hurt your external customer. However, internal customer's satisfaction yields significant insights for the organization (Credit Research Foundation, 1999). The study conducted by Rabinowitz (2006), operationalized internal customer satisfaction as communication, productivity and responsiveness. That is a three dimensional approach where communication measured the ability to communicate and listen effectively; productivity measured the ability to maintain high levels of efficiency, reliability and quality and responsiveness 
reflect the ability to respond effectively to customer needs. Toeing the same line, this study present study conceptualized internal customer's satisfaction as communication, productivity and responsiveness.

\subsection{Role Stressor}

Generally, role stressor has been described as the stress experienced by the employees or people in the organization due to their role or job in the organization. For instance, employees or people accept roles due to expectation of the self and others at work place. Role stressor involves the ambiguities experienced by workers in an organization, which could be as a result of job satisfaction and turnover intention (Zhang, Tsingan, \& Zhang, 2013). Role stressor had been discussed from three angles, (e.g., role conflict, role overload and role ambiguity) by various researchers' on organizational dynamics (Kahn, Wolfe, Quinn, \& Snoek, 1964; Zhang et al., 2013). Similarly, Hang-Yue, Foley and Loi (2005) classified role stressors into role conflict, role ambiguity, role overload and work-family conflict, but the two most commonly used are role conflict and ambiguity (Bettencourt \& Brown, 2003).

As an independent variable, role stressor in particular role ambiguity was found to have a significant positive relationship with personal skill development and performance (Babin \& Boles, 1996). Similarly, LeRouge, Nelson and Blanton (2006) also found that role stress was positively related to organizational commitment and job satisfaction but using self-esteem as a moderator between role stress and job satisfaction. Furthermore, an investigation by Lankau, Carlson and Nielson (2006) on the mediating role of role stressor shown that role stressor is a significant mediating variable. By classifying role stressor into two major dimensions of role ambiguity and role conflict as the two major indicators of role stressor in creating relationships between mentoring activities, vocational support, psychosocial support and prominent job attitudes, the study revealed that both role conflict and role ambiguity firmly mediated the relationships between psychosocial support and role modeling with job attitudes. In addition it also serves as a partial mediator of the relationship between vocational support and job attitudes. From the ongoing it is very clear that role stressor has been used in all levels of variables except at the level of a moderator. In this regarding, this study proposes role stressor as a moderator in the relationship between leadership change, behavourial change, structural change, technological change, cultural change and internal customer satisfaction. The presence of role stressor is assumed to strengthen the relationship between leadership change, behavourial change, technological change, structural change, cultural change and internal customer satisfaction. It is hoped that role stressor would interact with the independent variables (leadership change, behavourial change, technological change, structural change and cultural change) in such a way that it would have an impact at the level of dependent variable (internal customer satisfaction). Thus, role stressor will affect the direction of the association between leadership change, behavourial change, technological change, structural change, cultural change and internal customer satisfaction. Toeing the line of Lankau, Carlson and Nielson (2006) and in line the objective of this study, role stressor is here conceptualized as role ambiguity and role conflict. Thus, the study used two dimensions of role stressor which are role ambiguity and role conflict.

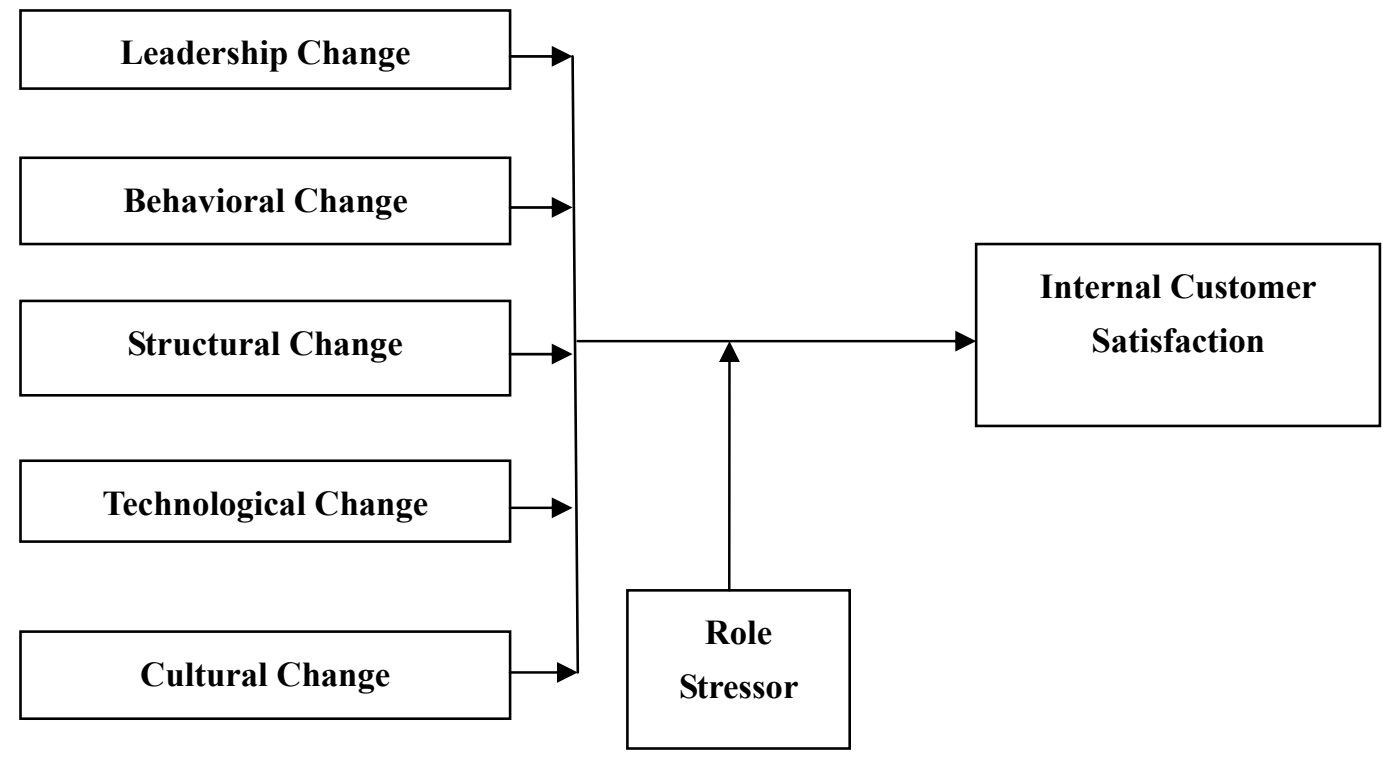

Figure1. Framework evaluation process change factor 
Building on this relevant literature, the following hypotheses are formulated:

H1: EPC factors will significantly influence internal customer satisfaction;

$\mathrm{H} 2$ : Role stressor will moderate the relationship between EPC factors and internal customer satisfaction;

H2a: Role stressor will moderate the relationship between Leadership change and internal customer satisfaction;

$\mathrm{H} 2 \mathrm{~b}$ : Role stressor will moderate the relationship between behavioural change and internal customer satisfaction;

$\mathrm{H} 2 \mathrm{c}$ : Role stressor will moderate the relationship between structural change and internal customer satisfaction;

H2d: Role stressor will moderate the relationship between technological change and internal customer satisfaction;

H2e: Role stressor will moderate the relationship between cultural change and internal customer satisfaction.

\section{Methodology}

\subsection{Research Design}

This is concerned with the methods and structures a researcher decides or chooses to adopt in getting his/her research done (Neil, 2009). This study adopts a cross-sectional study design technique since data collection is done in a single point at a particular time (Zikmund, Babin, Car, \& Graffin, 2013; Lucky \& Minai, 2011; Minai \& Lucky, 2011; Lucky \& Minai, 2012). This design is widely used in the social sciences domain and it can be done relatively quickly while the research data is all gathered at the same point in time. It also adopts the quantitative research approach, Sekaran, Robert and Brain (2001), the quantitative approach is widely applied in the field of social sciences and business field while Amin and Khan (2009); Khurshid (2008) and Ogbonnaya and Osiki (2007) concurred that quantitative research approach is very relevant in the social science studies of this nature.

\subsection{Population and Sampling Technique}

The population of this study covers the three major telecommunications (Orange, Zain, \& Umniah) in Jordan. It covers a total of number of 4,310 employees of Orange, Zain and Umniah telecommunication in Jordan who were identified through the three company's websites (Telecommunication Regulatory Commission Report, 2009). A disproportionate stratified sampling (DSS) technique was employed to select 354 respondents which was later increased to 500 respondents as Sekaran, Robert and Brain (2001) and, Krejcie and Morgan (1970). The use of DSS is to improve the representativeness of the sample which simple random sampling technique cannot assure (Olajide, 2007).

The unit of analysis for this study is at the individual level which covers the individual employees of three major telecommunication companies in Jordan. The use of these employees is justified as they are practitioners of the EPC and ICS concepts, process owners and are generally experienced with EPC practices. A self-administered questionnaire otherwise called drop-off and pick procedure served as the data collection method. This procedure compelled the researcher to move from location to another and gives the questionnaire to the respondents to fill up and later come back to pick up the filled questionnaire. This study has a response rate of $53 \%$ which is greater than the minimum response rate recommended The American Association for Opinion Research (AAPOR) in social science studies as reported by Johnson and Owens (2003).

\subsection{Measurement of Constructs}

In this study, all variables were measured using the 5-point scale, ranging from 1 (strongly disagree) to 5 (strongly agree) based on the previews of works of Lucky and Minai (2011); Minai and Lucky (2011) and Lucky and Minai, (2012); Zhang and Fang (2000) and Amin and Khan (2009). The questionnaire instruments were used to measure the extent on which the respondents agreed or disagreed on the research items. In all, there are a total of six variables in this study. Details about their measurement are as follow.

Concerning the leadership change variable, a total of ten (10) items adopted from Terziovski (2006); Samson and Terziovski (1999) were used to measure the variable. Behavioural change variable, ten (10) items adopted from the previous works by Terziovski (2006); Samson and Terziovski (1999); Mowday et al. (1979); Boles et al. (2007). Furthermore, ten (10) items also adopted from the work of Terziovski (2006); and Samson and Terziovski (1999); Ooi et al. (2007) were used to measure the structural change variable. With regards to the technological change variable, eleven (11) instruments adopted from previous study by Terziovski (2006); Samson and Terziovski (1999) were used to measure the variable. The items measure the extent to which the respondents agree or disagree with the instruments. Apart from that, role stressor which reflects two dimensions: role conflict and role ambiguity, was also measured using a total of 14 items, 8 items for the role conflict while 
the other 6 items for the role ambiguity respectively with the items adapted from the work by Siegall (2000). Also, ten (10) items adopted from the work of Lau and Idris (2001); Ooi et al. (2007); Zhang et al. (2000) was equally used to measure cultural change, and finally, the dependent variable which is internal customers' satisfaction was measured using 11 items adopted form the work of Worren, Moore, and Cardona (2002).

\section{Analysis and Results}

\subsection{Descriptive Analysis Result}

The descriptive analysis result conducted demonstrates that $87(32.8 \%)$ of the respondents are from the Zain telecommunication, the majority of the respondents, $128(47.5 \%)$ is from Orange while $52(19.6 \%)$ of the respondents are from the Umniah telecommunication. The result indicates that the employees of the three companies (Zain, Orange and Unniah) are more than 501. Similarly, the result also shows that majority of the respondents, $237(89.4 \%)$ are male while the rest are female $28(10.6 \%)$. Accordingly, the result indicates that 20 (7.5\%) respondents are within the age bracket of 21-30 years, $106(40.0 \%)$ of them are within the age bracket of $31-40$ years, $119(44.9 \%)$ of them are in the age bracket of $41-50$ years while age of 20 of them are more than 50 (7.5) with a mean of 3.52 and standard deviation of .744. As for the education of the respondents, the result indicates that $21(7.9 \%)$ of them have diploma, $190(71.7 \%)$ of them have a bachelor degree, $47(17.7 \%)$ of them are with a master's degree while $7(2.7 \%)$ of them possess Ph.D degree with a mean of 3.15 and standard deviation of .584. Concerning the Telequalification, the result shows that all $265(100 \%)$ employees of the three companies (Zain, Orange and Umniah) have professional qualification. Regarding the job position, the result equally indicates that $5(1.9 \%)$ of the respondents are in the CEO positions, $45(17 \%)$ are chief of departments, $24(9.1 \%)$ are operation/production managers while the majority of them, $191(72.1 \%)$ are staff. Finally, the result concerning the number of years in the respondents' current position shows that $3(1.1 \%)$ of the respondents have been in their current position in less than one year, $26(9.8 \%)$ of them have spent between 1 to 2 years in their current position, $109(41.1 \%)$ of them have also spend between 3 to 5 years in their current positions while the majority of them, 127 (47.9\%) of the respondents are currently more than 5 years in their present position.

\subsection{Factor Analysis Result}

A factor analysis was conducted on the variables in order to check for their construct validity, that is, to see whether each item was able to measure what it intends to measure, a factor analysis was conducted. All the items were validated using the principal component analysis with a varimax rotation. Here, the factor loading required for each item to be included in the factor is 0.4 as suggested by (Atyeo, Adamson, \& Cant, 2001). The results for all the factor analyses conducted on all the variables for this study are explained in tables 1, 2, 3, 4, 5, 6 and 7 below.

Table 1. Factor analysis result for leadership change

\begin{tabular}{lll}
\hline Leadership change items & Code & Factor Loading 1 \\
\hline Our leadership style is participatory & LSC3 & .808 \\
Our leadership style encourages employees' collaboration & LSC6 & .775 \\
We participate in every decision making in our organization & LSC2 & .748 \\
We emphasis on charismatic leadership rather than authoritarian leadership & LSC9 & .724 \\
We influence the employees' behaviours and attitude towards organisational & LSC10 & .705 \\
change and re-positioning & LSC4 & .612 \\
Our leadership style encourages employees' cooperation & LSC1 & .517 \\
Our organisation encourages and supports changes towards transforming the & LSC5 & .500 \\
organization & & 3.7 \\
Our leadership style encourages employees' communication & & 37.33 \\
Eigenvalue & & .808 \\
Percentage of variance explained (\%) & & 784.935 \\
Kasier-Meyer-Olkin & & 45 \\
Bartletts' test of spericity approx. chi square & & .000 \\
df. & & \\
Sig. & & \\
\hline
\end{tabular}


Table 2. Factor analysis result of behavioral change

\begin{tabular}{lll}
\hline Behavioural change items & Code & Factor Loading 1 \\
\hline We ensure that our employees are motivated & BC5 & .803 \\
We ensure employees' job satisfaction in our organization & BC6 & .790 \\
We have positive attitude towards changes in our organization & BC8 & .778 \\
We are always willing and committed to support change in the organization & BC10 & .764 \\
We are very loyal to management with respect to change in the organization & BC9 & .755 \\
We make sure that employees attitude and behaviour are well checked and & BC7 & .650 \\
controlled & BC1 & .534 \\
We collaborate with our customers with regard to product/service change & & 3.8 \\
Eigenvalue & & 37.98 \\
Percentage of variance explained (\%) & & .849 \\
Kasier-Meyer-Olkin & & 749.167 \\
Bartletts' test of spericity approx. chi square & & 45 \\
df. & & .000 \\
Sig. & & \\
\hline
\end{tabular}

Table 3. Factor analysis result of structural change

\begin{tabular}{lll}
\hline Structural change items & Code & Factor Loading 1 \\
\hline We consider all aspects of our business units with respect to change & $\mathrm{SC3}$ & .751 \\
We consider process management in designing our product/service & $\mathrm{SC10}$ & .745 \\
We provide employees' benefits in line with change & $\mathrm{SC6}$ & .703 \\
We ensure that quality practice management align with current change & $\mathrm{SC} 8$ & .677 \\
We assess our overall performance in line with occurring (environmental) change & $\mathrm{SC7}$ & .670 \\
We show all processes involved in achieving our organizational objectives with & $\mathrm{SC} 2$ & .665 \\
respect to change & & .603 \\
We always follow process in designing our product/service and also in discharging & $\mathrm{SC11}$ & \\
our responsibilities & $\mathrm{SC} 9$ & .483 \\
We follow process in monitoring and controlling our business activities & $\mathrm{SC1}$ & .407 \\
Our plan is in line with future change that will occur in the organization & & 3.8 \\
Eigenvalue & & 37.98 \\
Percentage of variance explained (\%) & .800 \\
Kasier-Meyer-Olkin & & 731.102 \\
Bartletts' test of spericity approx. chi square & & 55 \\
df. & & .000 \\
Sig. & & \\
\hline
\end{tabular}

Table 4. Factor analysis result of technological change

\begin{tabular}{lll}
\hline Technological change items & Code & Factor Loading 1 \\
\hline We change the overall content of our website to align with new technology & TC4 & .849 \\
We update the information on our website & TC3 & .839 \\
We constantly change our animations on our website to suit the latest information & TC10 & .831 \\
We often obtain the latest information for information analysis & TC6 & .755 \\
\hline
\end{tabular}




\begin{tabular}{lll}
\hline Technological change items & Code & Factor Loading 1 \\
\hline We update the software in our organization & TC8 & .488 \\
We change the overall content of our website to align with new technology & TC2 & .482 \\
Eigenvalue & 3.3 \\
Percentage of variance explained (\%) & 32.61 \\
Kasier-Meyer-Olkin & .788 \\
Bartletts' test of spericity approx. chi square & 702.644 \\
df. & 45 \\
Sig. & .000 \\
\hline
\end{tabular}

Table 5. Factor analysis result of cultural change

\begin{tabular}{lll}
\hline Cultural change items & Code & Factor Loading 1 \\
\hline We are happy with one another during a change in the organization & CC4 & .777 \\
We have a positive reaction towards change in the organization & CC7 & .742 \\
We willingly and voluntarily accept change in the organization & CC6 & .751 \\
We usually experience labour turnover during change in the organization & CC5 & .633 \\
We highly depend on our employees to accomplish our organizational goals. & CC10 & .573 \\
We consider teamwork in handling change in the organization & CC1 & .575 \\
We stick together during the change process in the organization & CC2 & .400 \\
Eigenvalue & & 2.9 \\
Percentage of variance explained (\%) & & 29.4 \\
Kasier-Meyer-Olkin & & .730 \\
Bartletts' test of spericity approx. chi square & & 514.156 \\
df. & & 45 \\
Sig. & & .000 \\
\hline
\end{tabular}

Table 6. Factor analysis result for role conflict

\begin{tabular}{lll}
\hline RC items & Code & Factor Loading 1 \\
\hline Maintain company stability is a must. & RC7 & .652 \\
Minimize potential conflict is a must in every department. & RC5 & .638 \\
We should bend the rules to satisfy customers. & RC1 & .629 \\
Eigenvalue & & 1.6 \\
Percentage of variance explained (\%) & 20.30 \\
Kasier-Meyer-Olkin & .571 \\
Bartletts' test of spericity approx. chi square & & 120.387 \\
df. & & 28 \\
Sig. & & .000 \\
\hline
\end{tabular}

Table 7. Factor analysis result for role ambiguity

\begin{tabular}{lcc}
\hline Role Ambiguity Items & Code & Factor Loading 1 \\
\hline Periodically supervisor will evaluate employee performance. & RA2 & .784 \\
The satisfaction of supervisor evaluation related to the performance & RA3 & .760 \\
Satisfaction related to the decrease level of conflict & RA6 & .529 \\
Eigenvalue & & 1.6 \\
Percentage of variance explained (\%) & & 27.4 \\
\hline
\end{tabular}




\begin{tabular}{lc}
\hline Role Ambiguity Items & Code \\
\hline Kasier-Meyer-Olkin & .541 \\
Bartletts' test of spericity approx. chi square & 134.042 \\
df. & 15 \\
Sig. & .000 \\
\hline
\end{tabular}

Table 8. Factor analysis result of internal customer

\begin{tabular}{lll}
\hline Internal Customer Satisfaction Items & Code & Factor Loading 1 \\
\hline I feel fairly satisfied with my present job. & ICS5 & .749 \\
Most days I am enthusiastic about my work. & ICS6 & .723 \\
Company enhances flexibility towards the employee needs. & ICS2 & .720 \\
I find real enjoyment in my work. & ICS8 & .714 \\
Company is running transparently on administrative matters. & ICS4 & .653 \\
I consider my job rather unpleasant. & ICS9 & .635 \\
Each day of work seems like it will never end. & ICS7 & .594 \\
My company has a high concern about the customer complaints. & ICS11 & .515 \\
Eigenvalue & & 3.8 \\
Percentage of variance explained (\%) & & 34.18 \\
Kasier-Meyer-Olkin & & .795 \\
Bartletts' test of spericity approx. chi square & & 757.040 \\
df. & & 55 \\
Sig. & & .000 \\
\hline
\end{tabular}

\subsection{Reliability and Correlation results}

These were conducted using the reliability, descriptive and correlation tests analyses, and they were determined using the Cronbachs' Alpha, mean, standard deviation and r-value for correlations. Table 8 shows the detail results.

Table 9. Cronbachs' Alpha, mean, standard deviation and correlations of the variables

\begin{tabular}{|c|c|c|c|c|c|c|c|c|c|c|c|}
\hline Variables & $\alpha$ & $\mathrm{M}$ & SD & LC & $\mathrm{BC}$ & $\mathrm{SC}$ & TC & $\mathrm{CC}$ & RA & $\mathrm{CA}$ & ICS \\
\hline $\begin{array}{l}\text { Leadership } \\
\text { change }\end{array}$ & .831 & 3.57 & .712 & and 1 & & & & & & & \\
\hline $\begin{array}{l}\text { Behaviourl } \\
\text { change }\end{array}$ & .849 & 3.61 & .763 & $.832^{* *}$ & 1 & & & & & & \\
\hline $\begin{array}{l}\text { Structural } \\
\text { change }\end{array}$ & .816 & 3.65 & .631 & $.770^{* *}$ & $.783^{* *}$ & 1 & & & & & \\
\hline $\begin{array}{l}\text { Technological } \\
\text { change }\end{array}$ & .816 & 3.57 & .738 & $.772^{* *}$ & $.789^{* *}$ & $.732^{* *}$ & 1 & & & & \\
\hline Cultural change & .725 & 3.41 & .738 & $.759^{* *}$ & $.760^{* *}$ & $.758^{* *}$ & $.756^{* *}$ & 1 & & & \\
\hline Role Conflict & .471 & 4.18 & .610 & -.070 & -.104 & $.128^{*}$ & -.044 & .017 & 1 & & \\
\hline Role Ambiguity & .844 & 3.38 & .626 & $.205^{* *}$ & $.204^{* *}$ & $.188^{* *}$ & $.204^{* *}$ & $.223^{* *}$ & -.051 & 1 & \\
\hline $\begin{array}{l}\text { Internal } \\
\text { Customer } \\
\text { Satisfaction }\end{array}$ & .803 & 3.53 & .78 & $.695^{* *}$ & $.724^{* *}$ & $.640^{* *}$ & $.676^{* *}$ & $.695^{* *}$ & -.063 & $.159^{* *}$ & 1 \\
\hline
\end{tabular}

Note: $\mathrm{n}=,{ }^{*} \mathrm{p}<0.05,{ }^{*} \mathrm{p}<0.001$. 


\subsection{Regression Analysis Result}

The regression tests for the influence of leadership change, behavioral change, structural change, technological change and cultural change on internal customer satisfaction are indicated in table 5. The result shows that leadership change is significantly related to internal customer satisfaction with $\beta=0.695, p<0.001$. Similarly, the regression result in table above shows that behavioural change is significantly related to internal customer satisfaction with $\beta=0.724, p<0.001$ ). The result of the regression test conducted shown in table above indicates that structural change is significantly related to internal customer satisfaction with $\beta=0.460, p<$ 0.001).Concerning technological change variable, the result of the regression analysis in Table above shows that technological change is significantly related to internal customer satisfaction with $\beta=0.676, p<0.001$ ). As for the cultural change, the result of the regression shows that cultural change is significantly related to internal customer satisfaction with $\beta=0.695, \mathrm{p}<0.001$ ).

To further test for the moderating effect of roles stressor, a 3-step hierarchical regression analysis technique suggested by Baron and Kenny (1987) was utilized. The significant F change (Sig. F $\Delta$ ) was used to determine the moderating effect role stressor (role conflict and role ambiguity). The results are indicated in Table 9.

Table 10. Hierarchical regression result for moderating effect of role conflict

\begin{tabular}{lccccc}
\hline Variables & $\mathrm{R}^{2}$ & $\Delta \mathbf{R}^{2}$ & $\Delta \mathrm{F}$ & Beta & Sig. $\Delta \mathrm{F}$ \\
\hline Leadership change & .483 & .000 & .002 & .674 & $.966^{\mathrm{NS}}$ \\
Behavioral change & .524 & .001 & .001 & .393 & $.467^{\mathrm{NS}}$ \\
Structural change & .448 & .018 & 8.285 & -.247 & $.004^{* *}$ \\
Technological change & .464 & .458 & 2.920 & -.043 & $.089^{* *}$ \\
Cultural change & .489 & .000 & .222 & .919 & $.634^{\mathrm{NS}}$ \\
\hline
\end{tabular}

$* \mathrm{P}<0.1, * * \mathrm{p}<0.05, * * * \mathrm{p}<0.001$, Sig $=$ Significant, Not Sg. $=$ Not Significant

Table 11. The result of the moderating effect of role ambiguity

\begin{tabular}{llllll}
\hline Variables & $\mathrm{R}^{2}$ & $\Delta \mathrm{R}^{2}$ & $\Delta \mathrm{F}$ & Beta & Sig. $\Delta \mathrm{F}$ \\
\hline Leadership change & .486 & .003 & 1.525 & .399 & .218 \\
Behavioral change & .527 & .003 & 1.737 & .432 & $.189^{\mathrm{NS}}$ \\
Structural change & .404 & .000 & .002 & .632 &. $.966^{\mathrm{NS}}$ \\
Technological change & .457 & .000 & .054 & .676 & $.817^{\mathrm{NS}}$ \\
Cultural change & .491 & .485 & 4.031 & .695 & $.046^{* *}$ \\
\hline
\end{tabular}

${ }^{*} \mathrm{P}<0.1,{ }^{* *} \mathrm{p}<0.05,{ }^{* * *} \mathrm{p}<0.001$, Sig $=$ Significant, Not Sg. $=$ Not Significant

\section{Discussion and Conclusions}

This study investigated the moderating effect of Role stressor on the influence of EPC factors on internal customer satisfaction in the telecommunication in Jordan. It employed a 3-step hierarchical regression analyses technique suggested by Baron and Kenny (1987) to test the various hypotheses reflecting the indirect effect of role stressor on the direct relationships of the independent and dependent variables.

Overall, the study found support for the influence of leadership change, behavioral change, structural change, technological change and cultural change on internal customer satisfaction. This result is consistent with previous study by Stacey, Allison, Dadds, Roeger, Wood and Martin (2002) found that generally, change significantly affect the level of individual satisfaction. They noted that a 'high or positive change leads to satisfaction while no or negative change leads to low satisfaction'. The result suggests that leadership change, behavioral change, structural change, technological change and cultural change can significantly predict internal customer satisfaction. It further indicates that telecommunication companies can rely on EPC factors such as leadership change, behavioral change, structural change, technological change and cultural change in achieving an effective and a better internal customer satisfaction.

For the moderating effect result, the study found overall support for the moderating effect of role conflict and 
role ambiguity on the relationship between structural change, technological change and cultural change on internal customer satisfaction. These findings are consistent with previous study by Fried, Ben-David, Tiegs, Avital, and Yeverechyahu (2011) who found that role stressor is a significant moderating variable in a study of this nature.

In particular, the finding indicates a significant moderating role for role conflict on the structural change and internal customer satisfaction, and between technological change and internal customer satisfaction. This result supports a similar finding by Fried, Ben-David, Tiegs, Avital, and Yeverechyahu (2011) who affirmed that role stressor is a significant moderating variable. The result demonstrates a significant interaction between role conflict and structural change, and between role conflict and technological change to predict internal customer satisfaction. Thus, role conflict is a significant moderating factor that impact on internal customer satisfaction. Therefore, role conflict should be considered as important factor by the telecommunication companies to achieve an effective internal customer satisfaction. While, on the contrary, the results also show that role conflict failed to moderate the relationship between leadership change, behavioural change and cultural change on the internal customer satisfaction. The presence of the moderator, role conflict has helped to strength the relationship between structural change and internal customer satisfaction, and technological change and internal customer satisfaction.

Regarding the moderating effect of the role ambiguity, the finding shows that role ambiguity only moderates the relationship between cultural change and internal customer satisfaction. It shows that both role ambiguity and cultural change are statistically significant in predicting internal customer satisfaction. The finding affirms a similar study by Fried, Ben-David, Tiegs, Avital, and Yeverechyahu (2011) who found that that role ambiguity is a significant moderating variable. The result suggests that role ambiguity has helped in strengthen the relationship between cultural change and internal customer satisfaction. However, the result also demonstrated that role ambiguity does not moderate the relationship between leadership change, behavioural change, structural change and technological change on the internal customer satisfaction. Hence, the finding failed to support a similar study by Fried, Ben-David, Tiegs, Avital, and Yeverechyahu (2011) that found that role ambiguity is a significant moderating variable. Thus, there is no statistical significance on the moderating effect of role ambiguity on the relationship between leadership change, behavioural change, structural change and technological change on the internal customer satisfaction.

The output of this study is beneficial to both the telecommunication company and the policy makers in government. First, it would guide telecommunication industry in managing role conflict and prevent role ambiguity in the industry. Secondly, the findings would also guide the policy makers to develop and formulate a better policy for the telecommunication companies in Jordan. This study only considered EPC factors within a specific industry in particular telecommunication, future studies should considered other industries such as manufacturing and trading sectors which are equally relevant to further check for the important internal customer satisfaction. Also, additional study on the EPC factors using the qualitative method is also suggested for an in-depth understanding of EPC factors especially cultural change and behavioural change factors on internal customer satisfaction.

\section{References}

Adkins, B., \& Caldwell, D. (2004). Firm or subgroup culture: Where does fitting in matter most? Journal of Organizational Behaviour, 25(8), 969-978. http://dx.doi.org/10.1002/job.291

Adler, N. J., \& Gundersen, A. (2008). International dimensions of organizational behavior. South-Western Pub.

Aghion, P., Bloom, N., \& Reenen, J. V. (2013). Incomplete Contracts and the Internal Organization of Firms. NBER working paper.

Ali, A. Y. S., Sidow, M. A., \& Guleid, H. S. (2013). Leadership Styles and Job Satisfaction: Empirical Evidence from Mogadishu Universities. European Journal of Management Sciences and Economics, 1(1).

Al-Jalahma, R., \& Gallear, D. (2010). Exploring the relationships between core elements of TQM implementation. EMCIS, 4(1), 1-9.

Amin, H. U., \& Khan, A. R. (2009). Acquiring knowledge for evaluation of teachers' performance in higher education-Using a questionnaire. (IJCSIS) International Journal of Computer Science and Information Security, 2(1).

Andersen, T. J. (2004). Integrating decentralized strategy making and strategic planning processes in dynamic environments. Journal of Management $\quad$ Studies, $41(8), \quad$ 1271-1298. http://dx.doi.org/10.1111/j.1467-6486.2004.00475.x 
Anderson, E. W., Fornell, C. L., \& Rust, R. T. (1997). Customer Satisfaction, Productivity, and Profitability: Differences between Goods and Services. Journal Marketing Science, 16(2), 129-145. http://dx.doi.org/10.1287/mksc.16.2.129

Anton, J., \& Phelps, D. (2002). How to benchmark your call center. Retrieved April 24, 2013, from http://www.benchmarkportal.com/newsite/slides.tml

Appelbaum, S. H., Mitraud, A., Gailleur, J. F., Iacovella, M., Gerbasi, R., \& Ivanova, V. (2011). The impact of organizational change, structure and leadership on employee turnover: A case study. Journal of Business Case Studies (JBCS), 4(1), 21-38.

Argote, L., \& Miron-Spektor, E. (2011). Organizational learning: From experience to knowledge. Organization Science, 22(5), 1123-1137. http://dx.doi.org/10.1287/orsc.1100.0621

Attafar, A., Sadidi, M., Attafar, H., \& Shahin, A. (2013). The Role of Customer Knowledge Management (CKM) in Improving Organization-Customer Relationship. Middle-East Journal of Scientific Research, 13(6), 829-835.

Atyeo, J., Adamson, B., \& Cant, R. (2001). Managerial skills for new practitioners in Medical Radiation Sciences in Australia: Implications for the tertiary education sector. Radiography, 7(4), 235-248. http://dx.doi.org/10.1053/radi.2001.0337

Azhashemi, M. A., \& Ho, S. K. M. (1999). Achieving service excellence: A new Japanese approach versus the $\begin{array}{lllll}\text { European } & \text { framework. Managing } & \text { Service }\end{array}$ http://dx.doi.org/10.1108/09604529910248795

Babin, B. J., \& Boles, J. S. (1996). The effects of perceived co-worker involvement and supervisor support on service provider role stress, performance and job satisfaction. Journal of Retailing, 72(1). 57-75. http://dx.doi.org/10.1016/S0022-4359(96)90005-6

Baron, R., \& Kenny, D. (1986). The moderator-mediator variable distinction in social psychological conceptual, strategic, and statistical considerations. Journal of Personality and Social Psychology, 51(6), 1173-1182. http://dx.doi.org/10.1037/0022-3514.51.6.1173

Bettencourt, L. A., \& Brown, S. W. (1997). Relationships among workplace fairness, job satisfaction and prosocial service behaviors. Journal of Retailing, 73(1), 39-61. http://dx.doi.org/10.1016/S0022-4359(97)90014-2

Bettencourt, L. A., \& Brown, S. W. (2003). Role stressors and customer-oriented boundary-spanning behaviors in service organizations. Journal of the academy of Marketing Science, 31(4), 394-408. http://dx.doi.org/10.1177/0092070303255636

Bienstock, C. C., DeMoranville, C. W., \& Smith, R. K. (2003). Organizational Citizenship Behaviour and Service Quality. Journal of Services Marketing, 17(4), 357-378. http://dx.doi.org/10.1108/08876040310482775

Boles, J., Madupalli, R., Rutherford, B., \& Wood, J. A. (2007). The relationship of facets of salesperson job satisfaction with affective organizational commitment. Journal of Business and Industrial Marketing, 22(5), 311-321. http://dx.doi.org/10.1108/08858620710773440

Boyer, K. K., Hallowell, R., \& Roth, A. V. (2002). E-services: Operating strategy-a case study and a method for analyzing operational benefits. Journal of Operations Management, 20(2), 175-188. http://dx.doi.org/10.1016/S0272-6963(01)00093-6

Burke, R. R. (2002). Technology and the customer interface: What consumers want in the physical and virtual store. Journal of the Academy of Marketing Science, 30(4), 411-432. http://dx.doi.org/10.1177/009207002236914

Burman, R., \& Evans, A. J. (2008). Target Zero: A Culture of safety. Defense Aviation Safety Centre Journal 2008, 22-27.

Cangas, J. M. (1996). The self-assessment process at 1994 Euro quality winner, Ericsson SA. Managing Service Quality, 6(6), 17-20. http://dx.doi.org/10.1108/09604529610149176

Chryssoula, C., Evangelos, C., Panagiotis, K., \& Marianna, S. (2009). Examining the Relationship between Emotions, Customer Satisfaction and Future Behavioral Intentions in Agrotourism. Published in: TOURISMOS. An International Multidisciplinary Journal of Tourism, 4(4), 145-161.

Clark, J. A. (2006). Dogmas of Ethnicity. In E. Rata, \& R. Openshaw (Eds.), Public Policy and Ethnicity (pp. 
170-184). Basingstoke and New York: Palgrove Macmillan.

Clark, P. A., \& Staunton, N. (1989). Innovation in Technology and Organization. Routledge, London.

Credit Research Foundation. (1999). Identifying Internal Customers and Measuring Their Satisfaction. Retrieved 2013, from http://www.crfonline.org/orc/ca/ca-4.html

Degeratu, A. M., Rangaswamy, A., \& Wu, J. (2000). Consumer choice behavior in online and traditional supermarkets: The effects of brand name, price, and other search attributes. International Journal of Research in Marketing, 17(1), 55-78. http://dx.doi.org/10.1016/S0167-8116(00)00005-7

Denison, D. R., Haaland, S., \& Goelzer, P. (2004). Corporate Culture and Organizational Effectiveness: Is Asia Different From the Rest of the World? Organizational Dynamics, 33(1), 98-109. http://dx.doi.org/10.1016/j.orgdyn.2003.11.008

Detelin, S. E. (2002). Effects of leadership on organizational performance in Russian companies. Journal of Business Research, 55, 467-480. http://dx.doi.org/10.1016/S0148-2963(00)00174-0

Earl, D. (2004). What Is Internal Customer Service? A Definition and Case Study. Retrieved 2013, from http://www.donnaearltraining.com/Articles/InternalCustomerService.html

Fecikova, I. (2004). Research and concepts: An index method for measurement of customer satisfaction. The EPC Magazine, 16(1), 57-66.

Felfe, J., \& Heinitz, K. (2010). The impact of consensus and agreement of leadership perceptions on commitment, Organizational Citizenship Behaviour, and customer satisfaction. European Journal of Work and Organizational Psychology, 19(3), 279-303. http://dx.doi.org/10.1080/13594320802708070

Ferris, G. R., Arthur, M. M., Berkson, H. M., Kaplan, D. M., Harrell-Cook, G., \& Frink, D. D. (1998). Toward a social context theory of the human resource management-organization effectiveness relationship. Human Resource Management Review, 8(3), 235-264. http://dx.doi.org/10.1016/S1053-4822(98)90004-3

Filippini, R. (1997). Operations management research: Some reflections on evolution, models and empirical studies in OM. International Journal of Operations and Production Management, 17(7), 655-670. http://dx.doi.org/10.1108/01443579710175583

Fisher, C. D., \& To, M. L. (2012). Using experience sampling methodology in organizational behavior. Journal of Organizational Behavior, 33(7), 865-877. http://dx.doi.org/10.1002/job.1803

Fisk, R. P., Brown, S. W., \& Bitner, M. J. (1993). Tracking the evaluation of the services marketing literature. Journal of Retailing, 69(1), 61-103. http://dx.doi.org/10.1016/S0022-4359(05)80004-1

Fried, Y., Ben-David, H. A., Tiegs, R. B., Avital, N., \& Yeverechyahu, U. (2011). The interactive effect of role conflict and role ambiguity on job performance. Journal of Occupational and Organizational Psychology, 71(1), 19-27. http://dx.doi.org/10.1111/j.2044-8325.1998.tb00659.x

Ganz, M. (2010). Leading change: Leadership, organization, and social movements. Handbook of leadership theory and practice, 509-550.

Garvin, D. (1998). The processes of organization and management. Sloan management review, 4(4), 406-430. Retrieved from http://dialnet.unirioja.es/servlet/articulo? codigo $=2491554$

Gillespie, M. A., Denison, D. R., Haaland, S., Smerek, R., \& Neale, W. S. (2007). Linking organizational culture and customer satisfaction: Results from two companies in different industries. European journal of work and Organizational psychology.

Goetsch, D. L., \& Davis, S. B. (2010). Quality management for organizational excellence. Prentice Hall

Grandey, A. A., Goldberg, L., \& Pugh, S. D. (2011). Employee Satisfaction, Responsiveness, and Customer Satisfaction: Linkages and Boundary Conditions. Academy of Management Proceedings, 2011(1), 1-6. http://dx.doi.org/10.5465/AMBPP.2011.65869474

Griffin, R. W., \& Moorhead, G. (2011). Organizational behavior: Managing people and organizations. South-Western Pub.

Hall, R. H., \& Tolbert, P. S. (1977). Organizations. Prentice hall.

Hallerbach, A., Bauer, T., \& Reichert, M. (2010). Capturing variability in business process models: The Provop approach. Journal of Software Maintenance and Evolution: Research and Practice, 22(6-7), 519-546. http://dx.doi.org/10.1002/smr.491 
Hang-yue, N., Foley, A., \& Loi, R. (2005). Work role stressors and turnover intentions: A study of professional clergy in Hong Kong. The International Journal of Human Resource Management, 16, 2133-2146. http://dx.doi.org/10.1080/09585190500315141

Howell, J. M., \& Hall-Merenda, K. E. (1999). The ties that bind: The impact of leader member exchange, transformational and transactional leadership, and distance on predicting follower performance. Journal of Applied Psychology, 84, 680-694. http://dx.doi.org/10.1037/0021-9010.84.5.680

Jacobides, M. G. (2007). The inherent limits of organizational structure and the unfulfilled role of hierarchy: Lessons from a near-war. Organization Science, 18(3), 455-477. http://dx.doi.org/10.1287/orsc.1070.0278

Johnson, T., \& Owens, L. (2003). Survey response rate reporting in the professional literature. Annual Conference of the American Association for Public Opinion Research, 127-133.

Kahn, R. L., Wolfe, D. M., Quinn, R. P., Snoek, J. D., \& Rosenthal, R. A. (1964). Organizational stress: Studies in role conflict and ambiguity. New York: Wiley.

Karlsson, C., Parker, C., Hjerpe, M., \& Linnér, B. O. (2011). Looking for leaders: Perceptions of climate change leadership among climate change negotiation participants. Global Environmental Politics, 11(1), 89-107. http://dx.doi.org/10.1162/GLEP_a_00044

Khurshid, K. (2008). A study of the relationship between the professional qualifications of the teachers and academic performance of their students at secondary school level. International Journal of Human and Social Sciences, 3(6), 409-415.

Kish-Gephart, J. J., Harrison, D. A., \& Treviño, L. K. (2010). Bad apples, bad cases, and bad barrels: Meta-analytic evidence about sources of unethical decisions at work. Journal of Applied Psychology, 95(1), 1-31. http://dx.doi.org/10.1037/a0017103

Krejcie, R. V., \& Morgan, D. W. (1970). Determining sample size for research activities. Educational and Psychological Measurement, 30, 607-610.

Krell, T. C. (2000). Organizational longevity and technological change. Journal of Organizational Change Management, 13(1), 8-14. http://dx.doi.org/10.1108/09534810010310203

Lankau, M. J., Carlson, D. S., \& Nielson, T. R. (2006). The mediating influence of role stressors in the relationship between mentoring and job attitudes. Journal of Vocational Behavior, 68(2), 308-322. http://dx.doi.org/10.1016/j.jvb.2005.06.001

Larsstuen, A., \& Mikkelsen, L. N. (1999). Introduction to self-Assessment as driving force for continuous improvement and increased involvement of employees, Norwegian Society for Quality and Leadership, Oslo. Proceedings of the annual ego conference, 41(2), 181-190.

Lau, H. C., \& Idris, M. A. (2001). Research and concepts: The soft foundation of the critical success factors on TQM implementation in Malaysia. The TQM Magazine, 13(1), 51-60. http://dx.doi.org/10.1108/09544780110379480

LeRouge, C., Nelson, A., \& Blanton, J. E. (2006). The impact of role stress fit and self-esteem on the job attitudes of IT professionals. Journal Information and Management Archive, 43(8), 928-938. http://dx.doi.org/10.1016/j.im.2006.08.011

Lian, H., Ferris, D. L., \& Brown, D. J. (2012). Does taking the good with the bad make things worse? How abusive supervision and leader-member exchange interact to impact need satisfaction and organizational deviance. Organizational Behavior and Human Decision Processes, 117(1), 41-52. http://dx.doi.org/10.1016/j.obhdp.2011.10.003

Lucky, E. O. I., \& Minai, M. S. (2011). Re-investigating the effect of individual determinant, external factor and firm characteristics on small firm performance during economic downturn. African Journal of Business Management, 5(26), 10846-10854.

Lucky, E. O. I., \& Minai, M. S. (2012). An empirical examination of the effect of entrepreneurs' biological make-up on the firm performance. International Business Management, 6(6), 621-628. http://dx.doi.org/10.3923/ibm.2012.621.628

Luo, X., Wieseke, J., \& Homburg, C. (2012). Incentivizing CEOs to build customer-and employee-firm relations for higher customer satisfaction and firm value. Journal of the Academy of Marketing Science, 40(6), 745-758. http://dx.doi.org/10.1007/s11747-011-0290-1 
Luthans, F., \& Avolio, B. J. (2009). The "point" of positive organizational behavior. Journal of Organizational Behavior, 30(2), 291-307. http://dx.doi.org/10.1002/job.589

Lynch, Jr. J., \& Ariely, D. (2000). Wine online: Search costs affect competition on price, quality and distribution. Marketing Science, 19(1), 83-104. http://dx.doi.org/10.1287/mksc.19.1.83.15183

Lytle, R. S., Hom, P. W., \& Mokwa, M. P. (1998). A managerial measure of organizational service-orientation. Journal of Retailing, 74(4), 455-489. http://dx.doi.org/10.1016/S0022-4359(99)80104-3

Meuter, M. L., Ostrom, A. L., Roundtree, R. I., \& Bitner, M. J. (2000). Self-service technologies: Understanding customer satisfaction with technology based service encounters. Journal of Marketing, 64(3), 50-64. http://dx.doi.org/10.1509/jmkg.64.3.50.18024

Michalska-Cwiek, J. (2009). Enterprises evaluation according to the polish quality awards. Journal of Achievements in Materials and Manufacturing Engineering, 36(2), 199-206.

Minai, M. S., \& Lucky, O. I. E. (2011). The conceptual framework of the effect of location on the firm performance. Asian Social Science, 7(12), 110-118. http://dx.doi.org/10.5539/ass.v7n12p110

Mowday, R. T., Steers, R. M., \& Porter, L. W. (1979). The measure of organizational commitment. Journal of Vocational Behavior, 14(2), 224-247. http://dx.doi.org/10.1016/0001-8791(79)90072-1

Neil, J. (2009). Exploring research. New Jersey: Pearson Education International, Inc.

Nicholls, J. A. F., Gilbert, G. R., \& Roslow, S. (1998). Parsimonious measurement of customer satisfaction with personal service and the service setting. Journal of Consumer Marketing, 15(3), 239-253. http://dx.doi.org/10.1108/07363769810219116

Ogbonna, E., \& Harris, L. C. (2000). Leadership style, organizational culture and performance: empirical evidence from UK companies. International Journal of Human Resource Management, 11(4), 766-788. http://dx.doi.org/10.1080/09585190050075114

Ogbonnaya, U. I., \& Osiki, J. O. (2007). The impact of teacher qualification and subject major in teaching mathematics in Lesotho. African Journal of Cross-cultural Psychology and Sport Facilitation (AJCSF), 9, 37-48. http://dx.doi.org/10.4314/ajcpsf.v9i1.37614

Olajide, O. (2007). Introduction to research methodology. Ilupeju, Onipanu, Lagos: NiyanPrint and Publications.

Oliver, R. L. (2010). Customer satisfaction. Wiley International Encyclopedia of Marketing. http://dx.doi.org/10.1002/9781444316568.wiem03008

Ooi, K. B., Abu Bakar, N., Arumugam, V., Vellapan, L., \& Yin Loke, A. K. (2007). Does TQM influence employees job satisfaction. An empirical case analysis. International Journal of Quality and Reliability Management, 24(1), 62-77. http://dx.doi.org/10.1108/02656710710720330

Pallant, J. (2007). SPSS Survival manual: A step-by step guide to data analysis using SPSS for Windows (version 15). Australia: Allan and Unwin.

Parasuraman, A., Zeithaml, V. A., \& Berry, L. L. (1988). SERVQUAL: A multiple-item scale for measuring consumer perceptions of service quality. Journal of Retailing, 64(1), 12-40.

Rabinowitz, K. (2006). Internal Customer Satisfaction Questionnaire. Professional Development Group, Inc. Retrieved from http://www.prodevgrp.com/ICSQ_Sample.pdf

Ramasamy, R. (2005). Total Quality Management. Tata McGraw Hill.

Rashid, S. (2008). Impact of Organizational Culture on Customer Satisfaction: A Study of Practitioners in Public Relations and Corporate Communication Industry in Malaysia.

Ray, G., Muhanna, W. A., \& Barney, J. B. (2005). Information technology and the performance of the customer service process: Are source based analysis. MIS Quarterly, 29(4), 625-652.

Roberto, M. A., Levesque, L. C., \& Team, L. Y. (2012). The art of making change initiatives stick. Image.

Rowold, J., \& Schlotz, W. (2009). Transformational and Transactional Leadership and Followers' Chronic Stress, Kravis Leadership Institute. Leadership Review, 9, 35-48.

Samson, D., \& Terziovski, M. (1999). The relationship between total quality management practices and operational performance. Journal of Operations Management, 17(4), 393-409. http://dx.doi.org/10.1016/S0272-6963(98)00046-1

Samuel, G. (2005). The relationship between leadership and internal customer satisfaction within a motor 
manufacturing company in Gauteng. Master's thesis, Rhodes University.

Saroj, \& Sukanya. (2009). Found that both technology and technology related factors including technological change affect the satisfaction level of the customers in Indian PSBs.

Sekaran, U., Robert, Y. C., \& Brain, L. D. (2001). Applied business research (1st ed.). Australia: John Wiley and Sons Australian Ltd.

Shankar, V., Rangaswamy, A., \& Pusateri, M. (2001). The online medium and price sensitivity. College Park, MD: University of Maryland.

Shankar, V., Smith, A. K., \& Rangaswamy, A. (2003). Customer satisfaction and loyalty in online and offline environments. International journal of research in marketing, 20(2), 153-175. http://dx.doi.org/10.1016/S0167-8116(03)00016-8

Siegall, M. (2000). Putting the stress back into role stress: Improving the measurement of role conflict and role $\begin{array}{lllll}\text { ambiguity. Journal of Managerial } & \text { Psychology, } & \text { 15(5), } & \text { 427-439. }\end{array}$ http://dx.doi.org/10.1108/02683940010337176

Stacey, K., Allison, S., Dadds, V., Roeger, L., Wood, A., \& Martin, G. (2002). The Relationship between Change and Satisfaction. Parents' Experiences in a Child and Adolescent Mental Health Service, 23(2), 79-89.

Taylor, S. A., \& Baker, T. L. (1994). An assessment of the relationship between service quality and customer satisfaction in the formation of consumers' purchase intentions. Journal of Retailing, 70(2), 163-178. http://dx.doi.org/10.1016/0022-4359(94)90013-2

Telecommunication Regulatory Commission Report. (2009). Jordan.

Terziovski, M. (2006). Quality management practices and their relationship with customer satisfaction and productivity improvement. Management Research News, 29(7), 414-424. http://dx.doi.org/10.1108/01409170610690871

Vukmir, R. B. (2006). Customer satisfaction. International Journal of Health Care Quality Assurance, 19(1), 8-31. http://dx.doi.org/10.1108/09526860610642573

Wagner, T., Kegan, R., Lahey, L. L., Lemons, R. W., Garnier, J., Helsing, D., \& Rasmussen, H. T. (2010). Change leadership: A practical guide to transforming our schools. Jossey-Bass.

Yang, Y. F. (2011). Leadership and Satisfaction in Change Commitment 1. Psychological reports, 108(3), 717-736. http://dx.doi.org/10.2466/01.28.PR0.108.3.717-736

Zeithaml, V. A., Berry, L. L., \& Parasuraman, A. (1996). The behavioral consequences of service quality. Journal of Marketing, 60(2), 31-46. http://dx.doi.org/10.2307/1251929

Zhang, A., \& Fang, Y. (2000). Teachers' performance and its attitudinal antecedents. Nanyang Technological University, Singapore.

Zhang, R. P., Tsingan, L., \& Zhang, L. P. (2013). Role Stressors and Job Attitudes: A Mediated Model of Leader-Member Exchange. The Journal of Social Psychology, 153(5), 560-576. http://dx.doi.org/10.1080/00224545.2013.778812

Zhang, Z., Waszink, A. B., \& Wijngaard, J. (2000). An instrument for measuring TQM implementation for Chinese manufacturing companies. International Journal of Quality and Reliability Management, 17(7), 730-755. http://dx.doi.org/10.1108/02656710010315247

Zheng, W., Yang, B., \& McLean, G. N. (2010). Linking organizational culture, structure, strategy, and organizational effectiveness: Mediating role of knowledge management. Journal of Business Research, 63(7), 763-771. http://dx.doi.org/10.1016/j.jbusres.2009.06.005

Zikmund, W. G., Barry, J. B., Jon, C., \& Griffin, C. M. G. (2013). Business Research Methods (8th ed.).

Zink, K. J., \& Schmidt, A. (1998). Practice and implementation of self-assessment. International Journal of Quality Science, 3(2), 147-170. http://dx.doi.org/10.1108/13598539810211969

\section{Copyrights}

Copyright for this article is retained by the author(s), with first publication rights granted to the journal.

This is an open-access article distributed under the terms and conditions of the Creative Commons Attribution license (http://creativecommons.org/licenses/by/3.0/). 